individual human subjects of research, and to provide a framework within which medical research could flourish.

The essays begin with a thoughtprovoking philosophical discussion by $\mathrm{Dr} \mathrm{K}$ Boyd. His examination of $\mathrm{Dr}$ K W M Fulford's 'four principles' for research -- knowledge, necessity, benefit and consent - is particularly useful, as these principles can provide a theoretical framework for those whose duty it is to review research protocols. This essay is followed by an informative discussion of the role of the World Health Organisation by Dr M N G Dukes, which has been in a fairly strong and effective position in 'persuading, nudging, catalysing the development of consensus and generally guiding the world into a proper pattern of behaviour on health issues'.

Dr P Bennett then provides an excellent summary of the key concerns of the clinical investigator, which could also serve as a checklist for research ethics committees. Dr N $P$ Maurice, writing from the perspective of the pharmaceutical industry, describes the complexity of European drug trials because of different attitudes to the way human research should be carried out. He discusses the development of 'good clinical practice' and the rise in the 1960s of the disciplines of clinical pharmacology and pharmaceutical medicine.

Dr S L Nightingale of the United States Food and Drug Administration explains in his essay the details of the regulatory system governing clinical research on humans in the United States. This regulatory system is highly developed, with a comprehensive review structure (which includes monitoring standards of review) by institutional review boards (IRBs). $\mathrm{J}$ Dangoumau then discusses the responsibilities of research ethics committees in France, where recent legislation has established local Consultative Committees for the Protection of Individuals.

Mr B Wijnberg offers a comparative overview of legislation in different EEC countries regarding medical research on humans, and of aspects of international and EEC law which impinge on these experiments. He concludes that there is room for improvement.

Dr F Garcia-Alonso and Dr M A Serrano-Castro describe clinical research and its regulation in Spain. This is followed by a discussion of the role of the European Ethical Review Committee by its chairman, Dr W M Rosinga. Finally, Dr Fernand Sauer gives an overview of the ethical aspects of EEC pharmaceutical legislation.

In his concluding remarks the editor notes that there is diversity between countries of the EEC, because of cultural and legal differences. He also points out that there are important points of unity; for example, the almost universal recognition of the Declaration of Helsinki of the World Medical Association. The editor leaves us with a direction: 'to stimulate the establishment of ethical review committees throughout the EEC' and to provide a uniform standard of review across the community.

The symposium must have provided a very useful and informative exchange of views and perspectives, reflected to a certain extent in the essays. Arguably the essays do not examine each topic in enough depth; nonetheless, they certainly lay foundations for further discussion and collaboration between countries of the EEC.

CLAIRE GILBERT FOSTER Centre of Medical Law and Ethics, King's College, London

\section{Animal rights and human morality}

\section{Bernard E Rollin, Buffalo NY,} Prometheus Books, 1992, 248 pages, $£ 12.95 \mathrm{sc}$, revised edition

Bernard Rollin is the stockman's rather than the philosopher's philosopher, having learned his trade in head-on intellectual combat with ranchers, veterinarians and researchers. His preferred method of argument, he writes, is less like sumo than judo: 'I simply side-step and give you a slight encouraging push in the direction of your punch ... and thereby show you that the ideal I am pressing upon you is in fact a consequence of beliefs you yourself entertain' (page 25). Animal Rights and Human Morality abounds in such home-spun wisdom, deceptively simple, since what Rollin wears so lightly is good learning, soundly-based and painstakingly acquired. One does not become a professor of philosophy, physiology and biophysics, simply by rocking-chair moralising.

More than a decade after its first edition, this remains one of the best introductions to its subject, livel lucid and engaging. Its first chapter Moral theory and animals (which makes up about a third of the bools outlines relevant deontological and consequentialist features of tho debate, arguing convincingly that animals have interests and their owf telos, which ought to be respected. 'moral gestalt shift' in perspective however, is needed for most people to realise this, and Rollin is realist about the difficulties involved in bringing this about. A second (much shorter) chapter on Animal rights ant legal rights explores ways of shifting the legal focus from animals property to the rights and welfare $\overline{\text { AP }}$ the animals themselves. Realisn again informs Rollin's third chaptẹp on The use and abuse of animals if research, which proposes a utilitariad cost-benefit principle to determino whether the research should be done at all, and then against that back $_{\overline{\mathrm{T}}}$ ground, a rights principle to maxi mise the potential of the animats involved for living according to the nature.

What Rollin writes about the la $\vec{x}$ and research largely reflects pra@ic in the USA; and it is tempting to suggest that much of what he recorio mends has already been impleme under recent British legislation. $\mathrm{O} \overline{\overline{\mathbf{Q}}}$ the other hand, many of his com ments on education and attitudes ar pertinent on both sides of the Atlantic. His final short chapte Morality and pet animals, moreover, brings the ethics of our relationship t度 animals home in especially thoughtprovoking ways.

Despite its occasionally repetitive rhetoric, its omissions, the attribution (page 93) of 'we murder to dissect' to. Tennyson rather than Wordsworth and some clumsy carpentry in the make-up of the new edition, Anim Rights and Human Morality remains one of the most accessible, sympro thetic and challenging introductions. to an important area of current mord debate, whose complexities Rollin, acknowledges and enlightens.

KENNETH M BOYWू Institute of Medical Ethics Edinburgf

The rights of patients

George J Annas, Clifton, New Jersey Humana Press Inc, 1992, 328 pages $\$ 27.50$ 


\section{The New York State Task Force on Life and the Law; when others must choose - deciding for patients without capacity}

New York State Task Force, New

York, 1992, 288 pages, US\$15

The New York State Task Force on Life and the Law is rightly held in high regard the world over. Its members represent the multiplicity of religious, social and ethnic groups to be found in New York state, and its publications, and its proposals for legislation, are characterised by careful argument and a surprising degree of consensus. In this report, the task force argues strongly for people to be educated about advance directives, so that decisions about treatment when a patient has become incapacitated are made in accordance with his or her wishes. They also argue hard for people to appoint a proxy of their choice (1), with whom they have discussed their wishes in the health-care setting. But if no advance directive has been executed, and no proxy has been appointed, the task force argues that a surrogate should be appointed (in many cases the kind of person who might have been appointed as a proxy before the patient became incompetent to take decisions) to make decisions on the patient's behalf, as far as possible in accordance with his or her religious, philosophical and social views.

The report includes a limited discussion of why it is that relatively few people have in fact written such advance directives (2), and argues forcefully for individual rights and preferences to be respected. However, the conclusion is firm - the appointing of a surrogate is the way forward in highly charged and difficult situations, be they discussions about painful treatment which prolong life for a relatively short period, as in the case of some chemotherapies for cancer, or discussions to do with life-sustaining treatment for those in a persistent vegetative state, particularly relevant in the UK given the controversy over the court decision which permitted Tony Bland to die.

Rabbi David Bleich has produced a minority report, taking the traditional Jewish orthodox line that this mechanism should only be used in the case of life-sustaining treatment. He argues that the appointing of a surrogate as proposed is a way of ensuring that lifesustaining treatment can be discontinued, and disapproves. 'Permitting a surrogate to refuse life-sustaining treatment without the patient's authorization constitutes stark abnegation of preservation of life as a value in and of itself.' That is undoubtedly the classic orthodox Jewish line, but it makes modern medicine impossible, when technology allows us to keep alive those who have no life in any real sense, including those whose families wish to see no more suffering, and when there are others who receive no treatment because resources are not available for them. The idea that all life must always be preserved at all costs is an easy one to hold on to - but is unjustifiable in the modern world, with modern skills and modern rationing decisions.

Hence the importance of George Annas's book. It is written for an American audience, and some of it reads extremely strangely to us in the UK. But it is a thorough look at what is and is not possible, and where individual rights lie, in the health-care setting, written for those who have an interest but are not experts. Annas has a felicitous style, and although this book is written in a question and answer style which can so often be exceedingly irritating, it is a handy reference book for health-care workers, for patients, and for civil rights groups. Its relevance to a UK setting, however, is relatively limited, for reading these two works makes it clearer than ever that the UK's pragmatic approach, without generally accepted principles relating to patients' rights, is not necessarily the best way to run health services. Most British citizens would not wish to see the US system of health care in this country, regarding the use of technology to preserve and prolong life with a certain amount of caution and even fear. But they might wish to see a more consistent approach to decision-making, as well as the strengthening of the view that the patient's perception of his or her own best interests should take precedence over a health-care professional's. We too need a task force to debate these issues rationally, from a variety of perspectives, and we too need to understand that ethics committees are needed for treatment decisions as well as research decisions, and that we have, thus far, simply pulled up the blankets over our faces, and ignored some of the hardest decisionmaking, thinking it would go away.

\section{References}

(1) New York State Task Force on Life and the Law. Life-sustaining treatment: making decisions and appointing a health care agent. 1987.

(2) Emanuel L L, et al. Advance directives for medical care - a case for greater use. New England journal of medicine 1991; 324: 889-895.

JULIA NEUBERGER

Camden and Islington Community Health Services NHS Trust, London

\section{Books: information and orders}

If you wish to order or require further information regarding the titles reviewed here, please write to or telephone the BMJ Bookshop, PO Box 295, London WC1H 9JR. Tel: 071383 6244. Fax: 0713836662. Books are supplied post free in the UK and for BFPO addresses. Overseas customers should add 15 per cent for postage and packing. Payment can be made by cheque in sterling drawn on a UK bank or by credit card (Mastercard, Visa, or American Express, stating card number, expiry date, and full name (The price and availability are occasionally subject to revision by the publishers). 